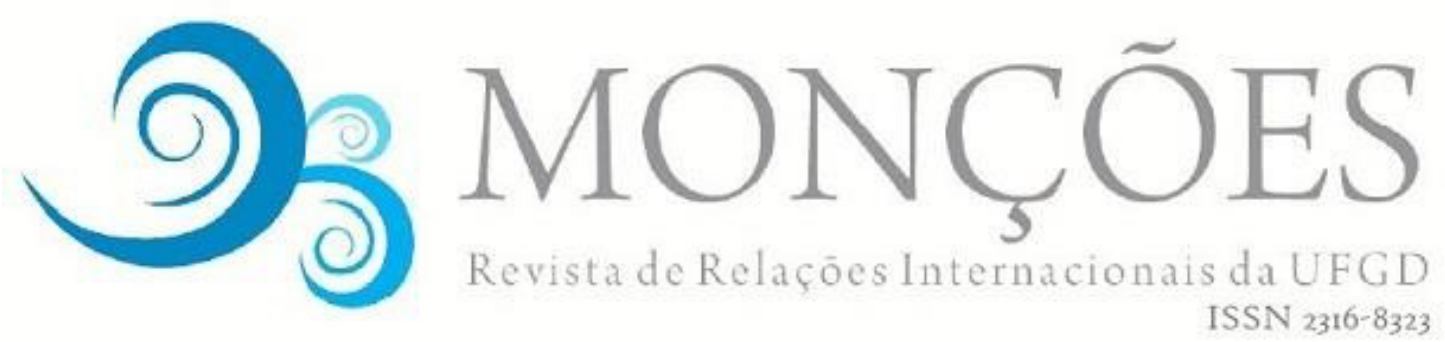

\title{
POLÍTICA DE ACESSO AO ENSINO SUPERIOR E O SONHO DO DIPLOMA DIÁSPORA HAITIANO
}

\author{
Bruna Ribeiro Troitinho \\ Doutoranda em Ciências Sociais na Universidade Federal de \\ Santa Maria \\ brunari.troitinho@gmail.com
}

RESUMO: O sonho de muitos jovens haitianos é migrar para outro país para tornarse diáspora, um cidadão haitiano no exterior. Junto a este sonho, alguns almejam ingressar no ensino superior e voltar ao país com o diploma para ajudar a desenvolver o país ou mesmo utilizá-lo de forma simbólica como uma distinção em relação aos outros conterrâneos. A presente pesquisa se trata do "diploma diáspora", sonho perseguido por jovens haitianos que ingressaram na Universidade Federal de Santa Maria a partir da Política de acesso ao ensino superior resultada do convênio com a Cátedra Sérgio Vieira de Mello. A partir de uma etnografia realizada entre os anos de 2017 e 2018 com os primeiros ingressantes, a pesquisa apresenta como está a inserção de estudantes haitianos no contexto acadêmico da UFSM.

Palavras-chave: migração haitiana, diploma diáspora, política de acesso ao ensino superior.

\section{POLICY ACCESS TO HIGHER EDUCATION AND THE DREAM OF HAITIAN DIASPORA DIPLOMA}

ABSTRACT: The dream of many young Haitians is to migrate to another country to become a diaspora, a Haitian citizen abroad. Alongside this dream, some aim to enter higher education and return to the country with the diploma to help develop the country or even use it symbolically as a distinction about other countrymen. The present research deals with the diploma diaspora, dream pursued by young Haitians who joined the Federal University of Santa Maria from the policy of access to higher education resulting from the agreement with the Sérgio Vieira de Mello Cathedra. From an ethnography carried out between the years 2017 and 2018 with the first students, the research presents how is the insertion of Haitian students in the academic context of UFSM.

Keywords: Haitian migration, Diaspora Diploma, Policy on access to higher education. 


\section{INTRODUÇÃO}

"O caminho certo é a escola, é nossa porta de saída". Essa foi uma fala de Josaphat, homem, 40 anos, estudante de Ciências Econômicas na Universidade Federal de Santa Maria. O contexto desta frase é de um diálogo entre a autora deste texto e o estudante sobre o acesso ao ensino no Haiti. Em seu relato, Josaphat destacava a dificuldade em continuar os estudos em seu país. Ele era de uma família de agricultores da cidade de São Luís do Sul. "O Haiti de hoje não é o que conheci. Não tinha problema, tinha tudo pra comer, podia jogar comida fora. As pessoas jogavam as comidas como de milho". Com esse relato, Josaphat dizia que em sua época o Haiti tinha melhores condições, principalmente para os agricultores, como é o caso de sua família. No ensino fundamental, estudou na École Nationale de Saint Louis du Sud (Escola Nacional de São Luís do Sul), uma das duas únicas escolas públicas da cidade. Josaphat morava a pouco mais de 5 quilômetros da cidade e, segundo ele, em março ajudava a família a colher milho, feijão e cana-deaçúcar. Quando decidiu cursar o ensino superior, se deparou com a necessidade de migrar para Porto Príncipe, onde estavam concentradas as instituições de ensino superior. Seu início foi em uma instituição particular, onde começou cursando Contabilidade. Em seu relato, com o terremoto de 2010, ele perdeu o apartamento da família na devastação e, sem oportunidade de emprego, sua saída foi migrar para estudar. Segundo ele, a oportunidade de saída do país era por meio do estudo.

Este artigo tem como objetivo contextualizar o conceito de diploma diáspora a partir da experiência haitiana na política de ingresso de refugiados e imigrantes em situação de vulnerabilidade na Universidade Federal de Santa Maria, no Rio Grande do Sul. Argumenta-se que os estudantes haitianos, maioria do público atendido por essa política, apresentam elementos culturais que proporcionam maior interesse no acesso ao Ensino Superior. A diáspora, no sentido haitiano, uma categoria de qualificação de pessoas e objetos a partir da experiência no estrangeiro, é uma das ferramentas analíticas dessa pesquisa.

A metodologia utilizada é a etnografia, realizada a partir da coleta de dados através da pesquisa de campo realizada entre os anos de 2017 e 2018, com um grupo de sete interlocutores. Defino como etnografia a conjunção do trabalho de campo, a interpretação dos dados e "descrição densa" dos resultados (GEERTZ, 
2008: GUBER, 2001; MALINOWSKI,1984). A etnografia também é resultado das relações sociais de troca estabelecidas entre pesquisadores e pesquisados que opera em diversos sentidos: o dar, receber e retribuir, constituindo, portanto, um "sistema de representações totais" ou fatos sociais totais (MAUSS, 2003).

Percebe-se na presente pesquisa o "dar" a partir da assessoria, por parte da pesquisadora e por intermédio do Grupo de Pesquisa, Ensino e Extensão Direitos Humanos e Mobilidade Humana Internacional responsável pela Cátedra Sérgio Vieira de Mello na adaptação e permanência dos estudantes ingressantes no ambiente acadêmico. A adaptação refere-se a questões de ordem burocrática - tais como as acadêmicas e as barreiras linguísticas culturais. O receber é compreendido pelas inúmeras informações sobre aspectos históricos e culturais que o grupo de estudantes haitianos compartilhou com a autora durante os dois anos de realização da pesquisa. Espera-se que a retribuição seja a socialização dos resultados alcançados por meio de trabalhos científicos que contribuam para o debate da migração e o acesso à educação.

Os interlocutores desta pesquisa são homens com idades entre 25 e 40 anos que estão no Brasil há mais de 3 anos, todos possuidores de visto humanitário. A fim de zelar pela integridade dos sujeitos da pesquisa e tendo em vista que se trata de um grupo vulnerável, o sigilo é uma escolha metodológica importante. Segundo Bourdieu (2008), cabe ao pesquisador se inteirar das estruturas de poder que envolvem o pesquisado de modo a evitar violências no decorrer da pesquisa e no posterior. Por isso, eles serão identificados a partir de nomes que os próprios estudantes escolheram no diálogo com a pesquisadora. Segue o mapa do Haiti com referência à cidade natal de cada um dos sujeitos dessa pesquisa. 
Figura 1 - Mapa do Haiti referente à localização dos estudantes.

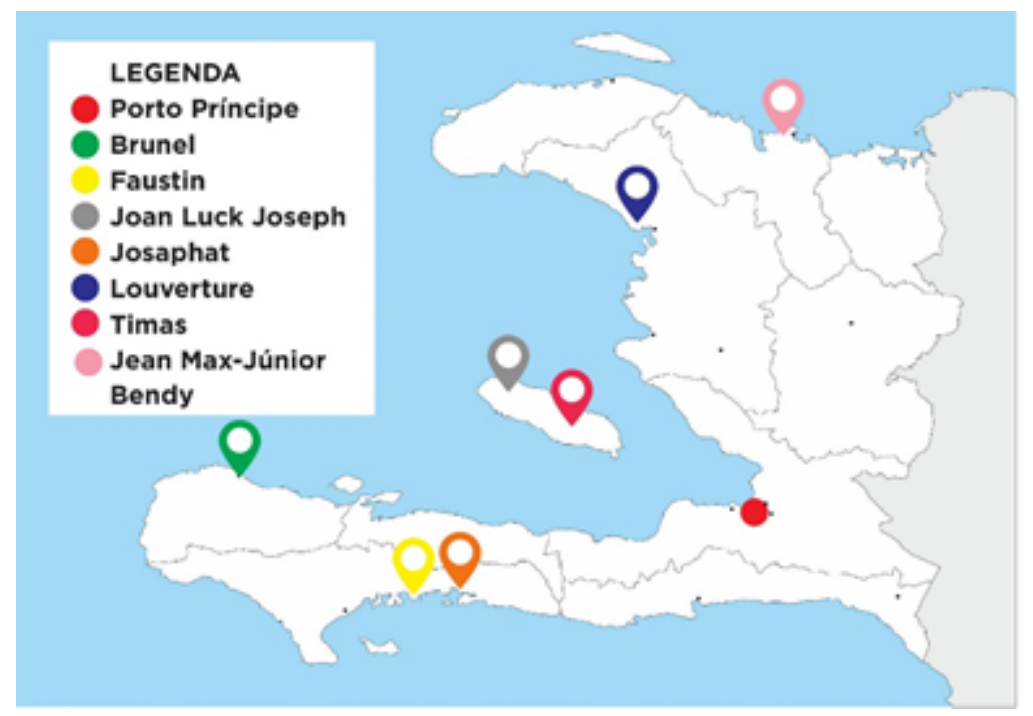

Fonte: Elaborado pela autora.

Esse mapa demonstra que nenhum dos interlocutores desta pesquisa é da capital Porto Príncipe, mas todos eles foram obrigados ao longo da sua vida acadêmica a migrar para Porto Príncipe para continuar os estudos. No Haiti, como grande parte do aparato estatal e das universidades se concentra na cidade de Porto Príncipe, isso ocasiona dificuldades para os estudantes que não residem nesse departamento. Por exemplo: os interlocutores Faustin e Josaphat são da zona rural de São Luís do Sul e suas histórias de vida são ligadas às dificuldades que os pequenos agricultores enfrentam no Haiti. No nível escolar, a cidade natal de ambos contava com apenas uma escola pública, onde ambos estudaram. Para terminar o ensino médio, no entanto, Faustin foi para Porto Príncipe, pois a qualidade das escolas públicas da zona rural era inferior se comparadas com as da capital. Ademais, eles relataram os obstáculos que encontraram para ingressar na Universidade do Estado do Haiti (UEH), a única instituição pública de ensino superior do país.

Dessa forma, a justificativa acadêmica da presente pesquisa é a contribuição antropológica para a análise das políticas de acesso ao ensino superior para migrantes e refugiados. Ademais, pretende-se contribuir com as pesquisas no campo das migrações que, em sua maioria, analisam a migração a partir do contexto do trabalho. Este artigo busca auxiliar na aceitação da presença do sujeito migrante em lugares como a UFSM. Conforme Sayad (1998), o migrante é, para o Estado de 
residência, uma força de trabalho em trânsito. A justificativa social é, portanto, conceber que o ambiente universitário também é lugar do sujeito migrante e romper com a racionalidade que aceita a presença do outro somente se ele estiver no mercado de trabalho.

O artigo está dividido em quatro seções: a) Estudantes Haitianos no Ensino Superior Brasileiro; b) A política de Acesso ao Ensino Superior de Refugiados e Migrantes em Situação de Vulnerabilidade na UFSM; c) o sonho diploma diáspora haitiano; d) inserção dos estudantes haitianos no ambiente acadêmico da UFSM. A primeira seção é dedicada à apresentação do Programa Pró-Haiti, a fim de contextualizar as relações entre o Brasil e o Haiti no que tange à educação. Já a segunda seção descreve a implementação da política de ingresso na UFSM. A terceira diz respeito às narrativas dos estudantes haitianos a respeito da educação superior e categoria moral do diploma estrangeiro na cultura haitiana. A última seção apresenta as inserções dos estudantes haitianos no contexto acadêmico da universidade em questão.

\section{ESTUDANTES HAITIANOS NO ENSINO SUPERIOR BRASILEIRO}

O Brasil mantém relações diplomáticas com o Haiti desde 1928, contudo, elas se tornaram mais notórias após 2010. O Estado brasileiro comandou a Missão das Nações Unidas para Estabilização do Haiti (MINUSTAH), a qual ajudou também na aproximação cultural entre os dois países. No ano de 2010, com o terremoto, o fluxo de migração de haitianos para o Brasil aumentou. Houve reforço das relações bilaterais entre esses países com a assinatura do "Memorando de entendimento entre o Governo da República Federativa do Brasil e o Governo da República do Haiti para a reconstrução, o fortalecimento e a recomposição do Sistema de Educação Superior do Haiti”.

Ainda em 2010, por meio da Portaria n 092/2010 editada pela Coordenação de Aperfeiçoamento de Pessoal de Nível Superior (CAPES), entrou em vigor o Programa Emergencial Pró-Haiti em Educação Superior, cujo objetivo era promover atividades para auxiliar a reconstrução das universidades haitianas e conceder bolsas universitárias a haitianos para concluírem seus estudos no Brasil na modalidade sanduíche. De acordo com o programa, seria dada prioridade para os 
seguintes cursos: Enfermagem, Medicina, Arquitetura e Urbanismo, Engenharias, Informática, Agronomia, Medicina Veterinária. Para concorrer às bolsas ofertadas, a exigência era ser haitiano, ser estudante de alguma IES haitiana e não possuir visto permanente ou temporário no Brasil.

Conforme a análise de Alphonse e Macedo (2017) sobre o Pró-Haiti de 2011 a 2016 , das 500 bolsas prometidas, o programa selecionou somente 89 alunos para quatro universidades federais do Brasil. O problema, de acordo com os autores citados, é que o Brasil novamente aproximou-se do Haiti com o intuito de garantir a visibilidade internacional para sua campanha de assento no Conselho de Segurança da ONU. Na perspectiva desses autores, o Brasil ficou devendo ao Haiti a promessa de contribuir com a reconstrução do país. Se por um lado o Estado brasileiro, por meio do Pró-Haiti, não conseguiu inserir mais estudantes haitianos nas universidades brasileiras, as próprias instituições, com a sua autonomia, promoveram ações que supriram parcialmente a promessa não cumprida por completo pelo Estado brasileiro.

As Instituições de Ensino Superior, baseadas em sua autonomia universitária e a partir do convênio com a Cátedra Sérgio Vieira de Mello ${ }^{1}$ (CSVM), abriram novas oportunidades ao sonho de muitos haitianos de conquistar o diploma no ensino superior. A Cátedra Sérgio Vieira de Mello objetiva promover o ensino, pesquisa e extensão acadêmica voltada para a condição de refúgio. O convênio entre as IES e a CSVM prevê que as universidades façam processos seletivos diferenciados para o ingresso de refugiados e revalidem os diplomas. Algumas instituições ampliaram o acesso à política para migrantes em situação de vulnerabilidade, onde se encaixam os migrantes haitianos residentes no Brasil. Este é o caso da Universidade Federal de Santa Maria, no Rio Grande do Sul, onde a presente pesquisa foi realizada. A cidade de Santa Maria se localiza na região central do estado do Rio Grande do Sul, não possui um polo industrial que atraia empregos, sendo reconhecida pelo ensino universitário: o município foi o primeiro do interior do Brasil a sediar uma universidade pública federal, fundada em 1960.

\footnotetext{
1 Segundo Relatório Anual da Cátedra Sérgio Vieira de Mello, de 2019, são 22 universidades conveniadas, destas 20 oferecem disciplinas voltadas a imigração e refúgio, 18 realizam pesquisas sobre o tema e 19 extensão voltada à temática. No que tange a Educação para Refugiados, 13 possuem o ingresso facilitado e 8 desenvolvem instrumentos próprios de revalidação do diploma (CSVM, 2019).
} 


\title{
A POLÍTICA DE ACESSO AO ENSINO SUPERIOR DE REFUGIADOS E MIGRANTES EM SITUAÇÃO DE VULNERABILIDADE NA UFSM
}

A proposta da Política de Acesso ao Ensino Superior de Refugiados e Migrantes surgiu a partir das pesquisas de campo realizadas pelo Grupo de Pesquisa, Ensino e Extensão Direitos Humanos e Mobilidade Humana Internacional (MIGRAIDH). No ano de 2014, integrantes do MIGRAIDH visitaram cidades gaúchas com concentração de migrantes objetivando compreender quais eram as demandas dessa população. As cidades de Lajeado e Caxias do Sul apresentam uma concentração de haitianos e senegaleses devido à maior oferta de emprego devido às indústrias sediadas nestes municípios. Segundo relatos dos pesquisadores do MIGRAIDH, a demanda maior por parte das comunidades migrantes era o acesso ao ensino superior, o qual era dificultado pela situação de migrante.

\footnotetext{
"Muitos falavam enfaticamente:

- Nossa eu quero estudar! Eu vim aqui porque eu quero estudar. Eu não consigo, falta alguma coisa burocrática como o Enem, vestibular e uma série de impossibilidades para chegar ao Ensino Superior" (Entrevista com integrante do MIGRAIDH realizada 04/04/2018).
}

A partir desta demanda, iniciou-se um estudo por parte dos estudantes e professores vinculados ao MIGRAIDH sobre a possibilidade de ingresso de migrantes na própria UFSM. Percebeu-se que a instituição tinha uma normativa engessada na condição de refúgio que não representava a realidade migratória do estado do Rio Grande do Sul. Ao final de 2014, os pesquisadores enviaram à PróReitora de Graduação (PROGRAD) a proposta da Resolução 041/2016, que foi discutida em outras Pró-Reitoras.

\begin{abstract}
"Ela [a resolução] foi se moldando ao longo do tempo e nós assinamos o acordo com o ACNUR em setembro de 2015, instituindo a Cátedra Sérgio Vieira de Mello, a qual nós [MIGRAIDH] seríamos os responsáveis. Na reunião solene de assinatura, vieram representantes do ACNUR, o Reitor, as autoridades participaram e falaram da importância do momento, e aí chegou-se a comentar um pouco sobre a importância da resolução. Nesse momento, houve um diálogo com a Reitoria sobre uma ligação do Secretário Nacional de Justiça, que falou sobre a importância da universidade se inserir no tema do refúgio, da importância do tema, enfim, da universidade estar aberta a participar disso, já que ele também havia sido convidado, mas por diversos motivos não pôde vir. Ali, o tema das migrações tomou uma dimensão maior na universidade, uma
\end{abstract}


dimensão institucional. Por meio da Cátedra, assumiu uma responsabilidade com o ACNUR e, de certa forma, com o Ministério da Justiça com o CONARE, que passou a incentivar mais as Cátedras naquele momento. Depois disso, ela seguiu sendo discutida nas Pró-Reitoras, pelo Fórum de Graduação, até que, em 2016, em 21 de outubro, ela passou pelo Conselho de Ensino Pesquisa e Extensão, o CEPE, e foi aprovada definitivamente. A partir disso, começou a se discutir como seria o ingresso para o ano de 2017, pois já queríamos que começasse logo" (Entrevista com integrante do MIGRAIDH realizada 04/04/2018).

Com a resolução, houve a criação na instituição de vagas suplementares que correspondem ao percentual de até $5 \%$ do número total das vagas de cada curso por intermédio da aprovação dos respectivos colegiados, independente do número de vagas ociosas (UFSM, 2016). A criação de vagas suplementares é um dos avanços que torna a resolução da UFSM uma das mais efetivas, pois cria vagas para o ingresso de ao menos um estudante em todos os cursos. Ao ampliar para migrantes em situação de vulnerabilidade, a mesma garante o acesso ao ensino superior dos haitianos, grupo vulnerável e que tem uma ampla presença no estado do Rio Grande do Sul. Isto porque, de acordo com a resolução, a situação de vulnerabilidade é "aquele portador do visto humanitário, ou permanente por razões humanitárias, emitido pelo Conselho Nacional de Imigração (CNIg)" ( UFSM, 2016).

A respeito do visto humanitário, cabe destacar que ele foi uma resposta do governo brasileiro ao aumento do fluxo migratório de haitianos para o Brasil, ocorrida a partir dos anos de 2010. O objetivo do governo brasileiro, com o visto humanitário, era organizar a migração de haitianos para o país, bem como impedir a migração irregular. Assim, a Resolução Normativa n.97/2012 criava as bases legais para a ordenação deste fluxo migratório.

Art. $1^{\circ}$ Ao nacional do Haiti poderá ser concedido o visto permanente previsto no art.16 da Lei $n^{\circ} 6.815$, de 19 de agosto de 1980, por razões humanitárias, condicionado ao prazo de 5 (cinco) anos, nos termos do art. 18 da mesma Lei, circunstância que constará da Cédula de Identidade do Estrangeiro.

Parágrafo único. Consideram-se razões humanitárias, para efeito desta Resolução Normativa, aquelas resultantes do agravamento das condições de vida da população haitiana em decorrência do terremoto ocorrido naquele país em 12 de janeiro de 2010 (CNIg, 2012, p.1). 
A concessão do visto humanitário não resolveu de imediato a situação migratória porque apresentava algumas exigências as quais tornavam o processo difícil para a maioria dos cidadãos haitianos. Com relação às exigências, destaco a posse do passaporte em dia, residência comprovada no Haiti, atestado de bons antecedentes e o pagamento de uma taxa de 200 dólares para a emissão do visto. Tendo em vista a desvalorização do Gourde, moeda haitiana, em relação ao dólar e a situação econômica da maioria das famílias haitianas que vivem com menos de dois dólares por dia, o valor da taxa do visto se torna muito seletiva. "Não era para qualquer haitiano o visto humanitário, esse valor de 200 dólares exige que as famílias façam muitos sacrifícios para nós chegar no Brasil" (Joan Luck Joseph, 25 anos, Engenharia da Computação).

O processo de ingresso de Refugiados e Migrantes em situação de vulnerabilidade garantiu a participação no ano de 2018 da UFSM, única brasileira, na reunião da Together $^{2}$ na Organização das Nações Unidas (ONU), lançada em 2016, com o objetivo de promover o respeito, segurança e dignidade a refugiados e migrantes, combatendo a xenofobia e a discriminação. A reunião que aconteceu em janeiro de 2018 selou o compromisso da universidade com o tema das migrações e do refúgio.

Ingressaram pela Resolução 041/2016 na UFSM até o primeiro semestre de 2018 cinquenta e dois estudantes, cuja maioria é do Haiti, mas estão divididos entre diversas nacionalidades, como se observa no gráfico de número 1. Os dados dos gráficos que serão apresentados nesta seção estão até o primeiro semestre de 2018 porque desde então não houve novos editais de ingresso para migrantes e refugiados.

\footnotetext{
${ }^{2}$ É uma iniciativa global liderada pelas Nações Unidas com o objetivo de mudar percepções e atitudes negativas em direção a migrantes e refugiados e fortalecer o contrato social entre as sociedades de residência, migrantes e refugiados. As estratégias da campanha são: (i) envolver e mobilizar cidadãos globais para mostrar suporte a migrantes e refugiados; (ii) falar às comunidades que hospedam migrantes e refugiados, bem como às pessoas que podem sentir alguma ameaça física ou econômica da presença de migrantes e refugiados; (iii) criar uma narrativa forte e persuasiva de solidariedade para com os migrantes e refugiados e mostrar os benefícios das migrações para as nações, respeitando as preocupações legítimas das nações receptoras; (iv) fornecer uma plataforma de histórias de e por refugiados e migrantes e das comunidades anfitriãs que se beneficiaram em recebê-los; (v) ajudar as comunidades, os migrantes e os refugiados a se conhecerem melhor (TOGETHER, 2018).
} 
Gráfico 1 - Nacionalidades dos ingressantes pela Resolução 041/2016 até o primeiro semestre de 2018

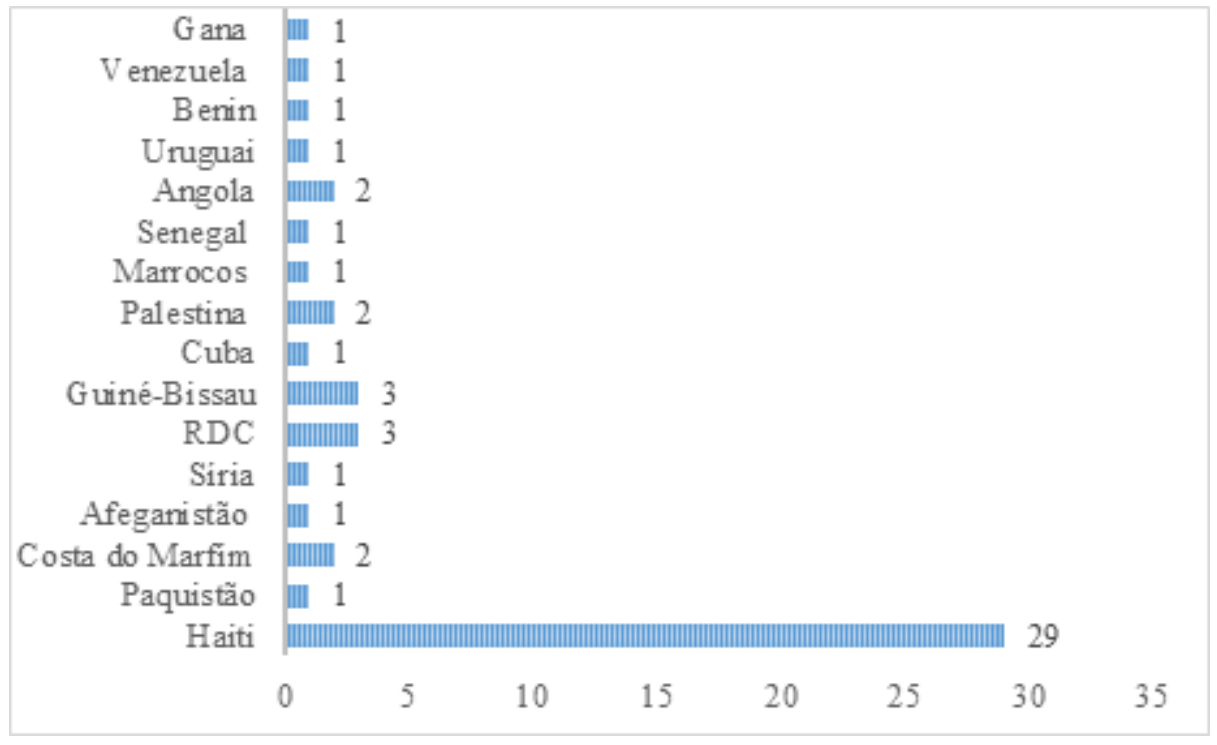

Fonte: Dados fornecidos pela Pró-Reitoria de Graduação da UFSM. Elaboração da autora.

Todos os ingressantes estão matriculados nos cursos de graduação. Há um único caso de uma ingressante que conseguiu aproveitar disciplinas cursadas em outra universidade brasileira e se formou ao final de 2017, representando uma exceção ao perfil dos ingressantes da resolução. Quanto aos cursos, a maioria escolheu cursos da área de exatas, principalmente as engenharias, conforme o gráfico a seguir. 
Gráfico $n^{\circ} 2$ - Distribuição dos estudantes nos cursos na UFSM até o primeiro semestre de 2018

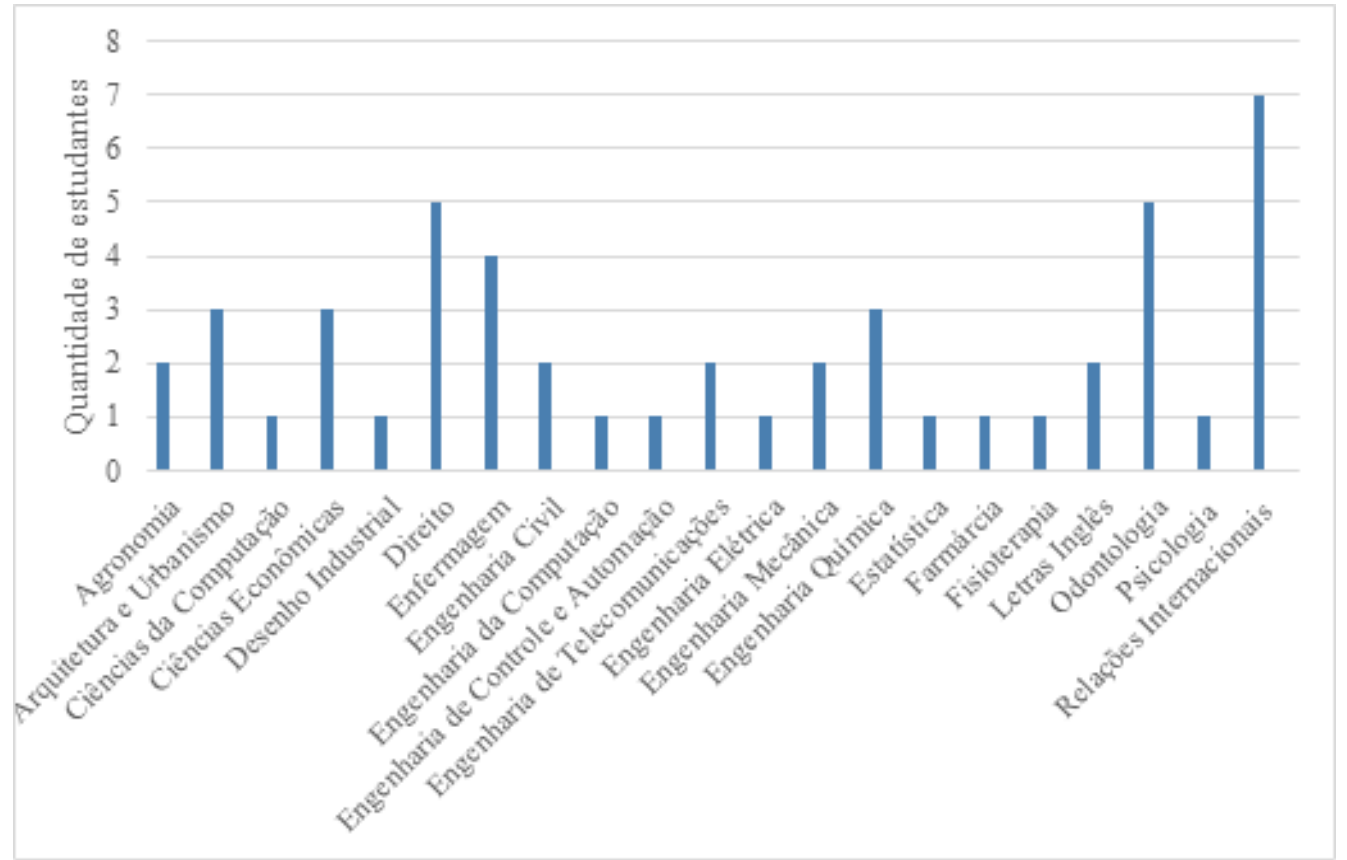

Dados fornecidos pela Pró-Reitoria de Graduação da UFSM. Elaboração da autora.

Os sujeitos que participam desta pesquisa salientam sua esperança em estudar algo que servirá para o ingresso no mercado de trabalho, seja no Brasil ou no seu país de origem. "Todos os haitianos que entram aqui querem fazer faculdade porque eles querem voltar com o diploma. Se você sai, tem que voltar com diploma para não se envergonhar da posição" (Joan Luck Joseph, 25 anos, Engenharia da Computação). Esta fala de Joan Luck Joseph salienta que o diploma, quando se trata da diáspora haitiana, ganha um novo significado: ele torna-se um símbolo de positivação da migração. Apesar de muitos não retornarem ao seu país de origem, o diploma se torna um marcador de diferenciação social, que demonstra prestígio e alcance do sucesso pretendido na migração. 
Gráfico 3 - Cursos frequentados pelos estudantes Haitianos na UFSM

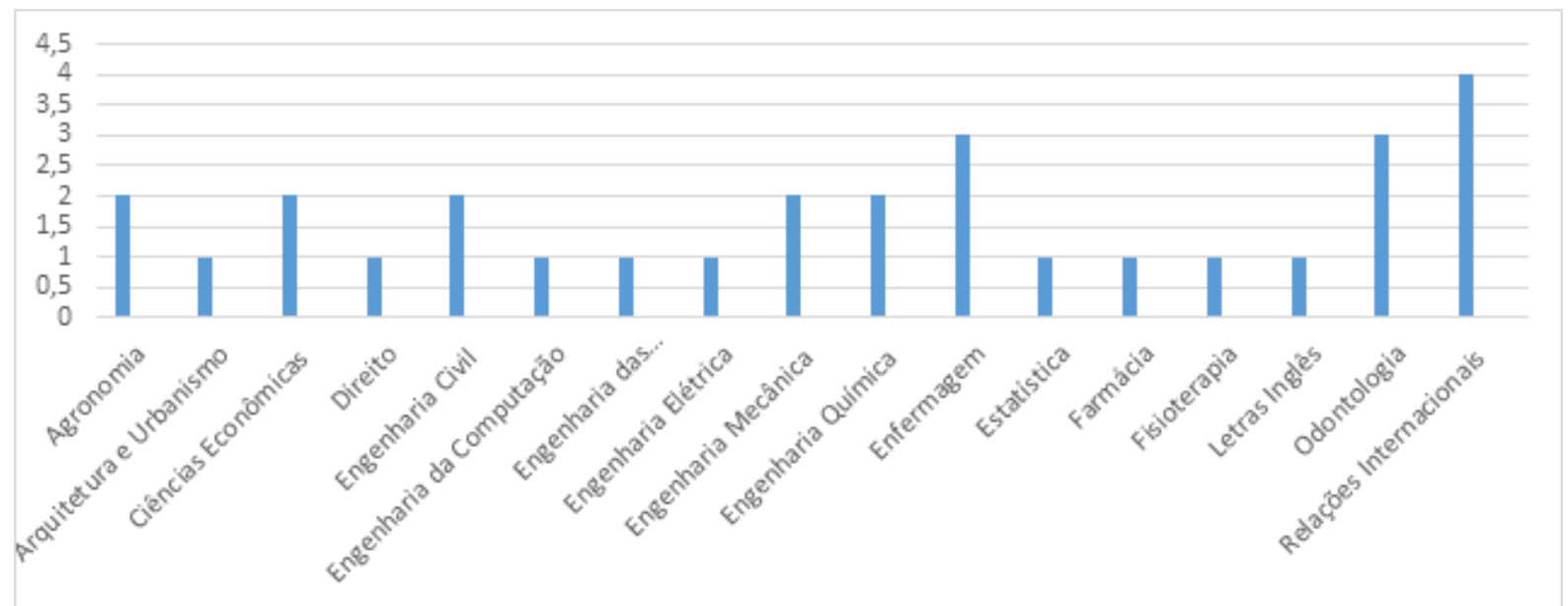

Dados fornecidos pela Pró-Reitoria de Graduação da UFSM. Elaboração da autora.

Sobre a área de saúde, uma das mais prestigiadas no Brasil, há poucos ingressantes porque muitos dos processos foram indeferidos pela coordenação do curso almejado. É o caso de Medicina, em que os estudantes foram realocados para outros cursos. Como o número de pedidos indeferidos pela medicina alcança quase 30 (entre os anos de 2017 e 2018), também foram poucos os que conseguiram ser realocados em outros cursos da saúde.

Com relação aos primeiros ingressantes da Resolução, o curso de Medicina apresentou um tensionamento, pois no primeiro edital de seleção alguns estudantes obtiveram sua inscrição deferida, condicionados à complementação dos documentos. Contudo, ao chegarem na UFSM para a realização da matrícula, descobriram que o colegiado havia negado o ingresso. Este é o caso de Timas.

Timas é natural da ilha de La Gonâve, migrou para Porto Príncipe quando ingressou em Bioquímica na Universidade do Estado do Haiti (UEH) e continuava a buscar o ingresso em medicina através da Université Quisqueya, na qual objetivava a migração para a França, país de residência do pai e alguns irmãos. Veio para o Brasil em 2014, após o falecimento do pai em busca de cursar Medicina aqui e "procurar fazer a vida também". Ele ingressou em Enfermagem na Universidade Federal da Fronteira Sul (UFFS) pelo Pró-Haiti e já estava avançado no curso quando recebeu a notícia da possibilidade de cursar Medicina na UFSM. "Eu fiquei muito feliz, era um sonho de muito tempo que estava para se realizar". Com o 
indeferimento do colegiado, Timas foi realocado para Enfermagem, refazendo algumas matérias que já havia cursado na UFFS.

\begin{abstract}
Observou que os indígenas que cursam Medicina na UFSM não estavam computados. Atualmente estão matriculados em torno de 6 indígenas mostrando um número total de alunos matriculados de 723 , mostrando que temos hoje no curso de medicina um número maior de alunos do que de vagas existentes, e não 717 alunos como indicado pela PROGRAD. O Prof. Jerônimo [Pró-Reitor de Graduação] voltou a afirmar que as vagas indígenas são vagas a mais do que o número de 120 ingressos anuais, oficialmente considerados. [...] O Prof. G. se manifestou ressaltando que independente dos indígenas serem vagas extras ou não, os mesmos são alunos regulares e devem ser computados como tal, sendo absurdo considerar que por terem seu ingresso de forma diferenciada os mesmos não sejam computados como alunos. Por fim deixou claro que a forma de ingresso extra cotas para indígenas foi uma decisão institucional da UFSM, tomada a nível superior, mas que a UFSM tem sido insistentemente comunicada formalmente, na última década, da situação caótica, em que vive o curso de medicina. Voltou a lembrar ao Pró-Reitor adjunto que no REUNI, em 2007, o curso de Medicina aumentou em $20 \%$ seu número de ingressantes, com promessa de contrapartidas do MEC no de aumento de áreas físicas, salas de aula, laboratórios, aumento do número de professores e de servidores técnico administrativos, e passados 10 anos nenhuma dessas contrapartidas foi efetivada (UFSM, 2017, ata da reunião do colegiado de medicina no dia 19/12/ 2017, grifo meu).
\end{abstract}

Conforme exposto na ata da reunião do colegiado do curso de Medicina, há um excesso de alunos para a capacidade da estrutura. A alegação dos professores é que o curso expandiu o número de alunos a partir do REUNI, mas que não houve aumento nos laboratórios, salas de aula, número de professores e nem técnicos administrativos. Por outro lado, destaca-se que a discussão em torno do ingresso de migrantes resultou numa discussão sobre os corpos que incomodam menos naquele ambiente, haja vista que além das condições estruturais, a presença de estudantes indígenas era constantemente trazida à discussão como responsáveis pela situação "caótica em que vive o curso de medicina" - mesmo que eles representassem menos de $1 \%$ dos estudantes do curso. Parafraseando Nilma Lino Gomes (2017), a discriminação no Brasil incide sobre o pertencimento étnico expresso em costumes e tradições circunscritos por sinais diacríticos inscritos no corpo, no caso o negro e indígena.

O curso de Medicina, desde a sua fundação em 1808, tem servido para a formação de uma elite profissional brasileira, cuja base epistêmica importada fora a francesa (CORADINI, 1997:2005). Portanto, apesar das políticas de cotas, alguns cursos de prestígio continuam mantendo o "confinamento racial" (CARVALHO, 
2006). O caso da UFSM não foge à regra nacional, conforme demonstra a tese de Maria Rita Py Dutra.

Conversando com um médico, professor do curso de Medicina, ele me alertou que há mais de $\mathbf{2 0}$ anos lecionando uma cadeira obrigatória, nunca passou por ele qualquer estudante negro, contudo há registro de que no período de 2008 a 2015, formaram-se 10 médicos negros (DUTRA, 2018, p.196, grifo meu).

Apesar dos esforços das Pró-Reitorias de Graduação e de Assuntos Estudantis, os estudantes ingressantes da resolução não conseguiram acessar o curso de Medicina. A cada semestre, novas negociações com o colegiado são iniciadas por parte de representantes do MIGRAIDH, das Pró-Reitorias citadas e dos próprios ingressantes. Contudo, nenhum avanço foi alcançado. Por outro lado, aqueles que estão em outros cursos da área da saúde conseguiram apoio no Departamento de Saúde Coletiva para desenvolverem suas pesquisas, criando o projeto Saúde pelo Haiti ou Santé pour Haiti, cujo objetivo é compreender o funcionamento do Sistema Único de Saúde (SUS) e pensar alternativas possíveis de saúde coletiva para o Haiti. A partir da situação do ingresso em Medicina, ressalto que o maior desafio da universidade até o momento é garantir que haja acesso nos cursos prestigiados da instituição dos estudantes ingressantes da Resolução 041/2016.

Sobre o sexo dos ingressantes, a maioria é constituída de homens. Há 11 mulheres até o momento, sendo que no ano de 2017 eram apenas duas. Por isso a maior parte dos interlocutores dessa pesquisa são homens. Desse número, quatro são do Haiti e estão nos cursos de Enfermagem, Fisioterapia e Odontologia. O número de ingressantes mulheres não é um dado isolado: ele reflete a realidade migratória das mulheres haitianas no Brasil, cujos números aumentaram significativamente desde a segunda geração da imigração, a partir de 2013, mas ainda continuam sendo um número pequeno se comparado com a imigração masculina (UEBEL, 2015). Até 2014, no estado do Rio Grande do Sul, dos 2503 imigrantes haitianos, 640 eram mulheres - um percentual de $25 \%$ da migração haitiana (UEBEL, 2015).

Além dos dados quantitativos, é preciso considerar a constituição das desigualdades de gênero no Haiti, cuja participação das mulheres na política é 
baixa. Segundo Louis Dantil (2016), há um entendimento de que a política haitiana é suja, portanto, inapta à participação das mulheres, vistas como elemento indispensável para o equilíbrio do lar. Um dos fatores que alargam a diferença na participação das mulheres em espaços políticos é o acesso à educação. São elas as mais prejudicadas no processo de exclusão sistemática promovida pelo Estado haitiano. De acordo com Nascimento e Thomaz (2010, p.22), a participação das mulheres haitianas em cursos superiores tem se mantido "extremamente baixa ao longo dos anos, e isso apesar de um desempenho escolar equiparável (ou mesmo melhor, diriam muitos) ao dos seus colegas".

\section{O SONHO DO DIPLOMA DIÁSPORA HAITIANO}

O termo diáspora foi utilizado para definir a dispersão física em grande quantidade de grupos religiosos, os quais passaram a viver como minoria em outras localidades, como caso clássico é a experiência dos judeus. Historicamente, o termo se amplia e descola sua definição para o que Cohen (1997, p.4) denomina como "uma vasta gama de povos diferentes que se auto aplicaram o termo ou tiveram o rótulo conferido a eles". Segundo Dufoix (2008), as populações referências no conceito até meados dos anos de 1980 eram os judeus, as pessoas de origem africana, palestinos e os chineses.

As definições a respeito do conceito de diáspora foram centrais nas discussões das Ciências Sociais, principalmente na década de 1990, em estudos sobre migrações e mobilidades. William Safran (1991, p.83-84) é um dos primeiros autores a formular um modelo ideal do conceito: 1) eles ou seus ancestrais se encontram dispersos a partir de um centro de origem, em no mínimo, dois espaços periféricos; 2) eles mantém uma memória mítica da terra de origem; 3) sentem que não são - e talvez, não podem ser - totalmente aceitos no país receptor; 4) veem sua terra natal como a casa ideal, na qual eles e seus descendentes podem retornar; 5) eles acreditam que podem manter ou reconstruir a terra de origem coletivamente na diáspora; 6) a consciência e solidariedade do grupo são definidas pela manutenção dos laços com a terra de origem. Robin Coehn (1997, p.18) também elaborou um modelo para definição do termo diáspora. Em seu modelo, existem cinco tipos: i) vítimas, cujos representantes são os judeus, africanos e armênios; ii) de trabalho ou "diáspora proletária", especialmente os indianos ; iii) 
imperial, britânicos e outros colonizadores; iv) comercial, chineses e libaneses; v) desterritorializados, caribenhos e grupos étnicos, como os Pársis e Sindis.

Existem diversos trabalhos que buscam definir o termo diáspora como um conceito fechado e analítico, principalmente William Safran (1991), Robin Coehn (1997), Stéphane Dufoix (2008), Gabriel Sheffer (2003). Em resumo, os autores elencavam algumas caraterísticas que permitiam a definição de um tipo ideal do conceito utilizável para definição de algumas comunidades. A experiência de dispersão deveria atingir algumas gerações (a ideia de longa duração), a reconstrução da memória com o lugar de origem e a dificuldade em se integrar à população do país receptor são alguns dos atributos da comunidade diaspórica para os pesquisadores (BRUNEAU, 2010).

Por outro lado, um grupo de autores definiu a diáspora como híbrida para diferenciá-la dos modelos centralizadores anteriormente expostos. O modelo híbrido foi muito usado por autores Pós-modernos, dos Estudos Culturais e Pós-colonial como James Clifford (1994), Stuart Hall (1990) e Paul Gilroy (2001). A respeito da diáspora híbrida, escreve Hall (1996, p.75): "A experiência da diáspora, como aqui pretendo, não é definida por pureza ou essência, mas pelo reconhecimento de uma diversidade e heterogeneidade necessárias; por uma concepção 'identidade' que vive com e através, não a despeito, da diferença; por hibridização". Da mesma forma, a proposta de Paul Gilroy é discutir uma "ideia diaspórica" para além das dicotomias simplistas que existiam nas discussões clássicas do conceito de diáspora. No Atlântico Negro, a ideia de cultura é desterritorializada em oposição à ideia de cultura fixa a um território nacional. "Sob a chave da diáspora, nós poderemos então ver não a raça, e sim formas geopolíticas e geoculturais de vida que são resultantes da interação entre sistemas comunicativos e contextos que elas não só incorporam, mas também modificam e transcendem" (GILROY, 2001, p. 25).

Em continuidade com esta perspectiva, o antropólogo James Clifford (1994) propõe traveling cultures em oposição aos modelos de natureza estática do termo diáspora. Importa o termo diaspora a partir de sua popularização entre migrantes haitianos nos Estados Unidos na década de 1980 (GLICK-SHILLER, 2011). Durante o período da ditadura duvallerista ${ }^{3}$ (1957 - 1986), a migração haitiana para os

\footnotetext{
3 Período do governo de François Duvalier, mais conhecido como Papa Doc, por ser um médico de prestígio no país. Sua eleição foi populista, mas logo implantou uma ditadura que causou muita emigração. Foi sucedido por
} 
Estados Unidos cresceu e foi constituindo uma comunidade haitiana nas periferias do país. É deste período histórico o fenômeno do boat people 4 .

$\mathrm{Na}$ presente pesquisa, o termo diáspora é usado como uma categoria organizadora de mundo para os haitianos. Conforme demonstra Handerson (2015) o termo polissêmico é articulado em três sentidos: residir no exterior, voltar ao Haiti e retornar ao Haiti.

\begin{abstract}
As músicas haitianas produzidas no exterior são chamadas músicas de diáspora. As roupas enviadas são denominadas rad diaspora (roupa diaspora); o dólar americano e o euro, lajan diaspora (moedas diaspora); as casas construídas no Haiti por compatriotas residentes no exterior, combinando objetos (eletrônicos e eletrodomésticos, etc.), materiais de construção (cerâmicas, portas, janelas, luzes, etc.) do exterior com os do país, são denominadas kay diaspora (casas diaspora). A categoria diáspora também serve para qualificar ações, como nas expressões: w’ap fè bagay diaspora (está fazendo coisa de diaspora), ou aji tankou diaspora (você age como diaspora) (HANDERSON, 2015, p.53).
\end{abstract}

Os sentidos políticos do termo diáspora foram expandidos quando, em 1991, o então presidente Jean-Bertrand Aristide recebeu a diáspora como o décimo primeiro departamento haitiano. Este ato simbólico representa o reconhecimento da participação social e política dos haitianos no exterior na vida cotidiana do país. Apesar disso, juridicamente, o Estado haitiano reconhece como haitiano somente aquele nascido em seu território, excluindo a possibilidade daqueles nascidos no exterior de reivindicarem a nacionalidade haitiana. Segundo Handerson (2015), no ano de 2012 foi promulgada uma emenda constitucional que permitia a dupla nacionalidade, oportunizando aqueles que estavam no exterior de ter o reconhecimento legal da ligação afetiva e simbólica com o Haiti.

Interessa, contudo, o pertencimento simbólico da diáspora desde o discurso de 1990 para pensar outros nacionalismos, ou um "nacionalismo à longa distância" (GLICK-SCHILLER; FOURON, 2001). Esse nacionalismo refere-se ao pertencimento dos migrantes ao país de origem, independente do país de residência. Os teóricos do transnacionalismo acreditam que o migrante desenvolve e mantém múltiplas

seu filho Jean-Claude Duvalier após sua morte em 1971. Conhecido como Baby Doc, Jean-Claude governou o Haiti até 1986.

${ }^{4}$ Fenômeno ocorrido entre meados de 1977 e 1981, quando um grande fluxo de migração haitiana clandestina se lançou ao mar para os Estados Unidos em barcos pouco equipados. Muitos haitianos morreram na travessia, seja pelos naufrágios ocasionados por problemas técnicos ou aqueles provocados pelas autoridades estadunidenses. De acordo com Stepick (1982), a maioria dos migrantes do fenômeno boat people eram pobres e da zona rural haitiana que buscam melhores condições. 
relações sociais que atravessam fronteiras, cujas decisões são pautadas a partir da experiência do país de origem e do de residência (SCHILLER et. al.,1992). A presente pesquisa parte da noção que a migração é um direito humano (REDIN, 2010), portanto, compreende-se a mobilidade humana e a circulação das pessoas enquanto partes integrantes dessas sociedades.

Dessa forma, importa para a manutenção dos laços entre o sujeito diáspora e o país, os laços de sangue, no caso a família que permanece no Haiti. A dimensão familiar é fulcral para compreender o pertencimento a uma nacionalidade mesmo distante fisicamente. "Não há diáspora sem a célula familiar, por meio da qual se transmite a consciência identitária. Tampouco não há diáspora sem laços de parentesco, real ou imaginário, ultrapassando as fronteiras estatais" (BRUNEAU, 2004 , p. 45, tradução minha). Esses laços que ultrapassam as fronteiras são alimentados de diversas formas: seja no envio de remessas do exterior (um dos mais comuns), a esperança de se juntar ao familiar no exterior ou na circulação de objetos enviados pelos parentes na diáspora.

Sobre essa relação com a mobilidade, apresento brevemente Brunel, interlocutor desta pesquisa, natural da cidade de Jérémie, capital do Departamento Grand'Anse, no oeste do Haiti. O primeiro movimento migratório de Brunel foi para a capital Porto Príncipe, a cerca de 300 quilômetros de Jérémie, quando ingressou em Engenharia Civil na Universidade do Estado do Haiti. As irmãs de Brunel migraram para os Estados Unidos na década de 1990 e foi com as remessas delas que o irmão se manteve em Porto Príncipe. A partir da experiência delas, Brunel alimentou o seu desejo de sair do Haiti.

Em busca de realizar esse sonho, Brunel conseguiu ir ao Brasil para estudos no ano de 2012 através do Programa Estudante Convênio Graduação (PEC-G). Ele ingressou em Engenharia Civil na Universidade Federal do Rio Grande do Sul (UFRGS) no mesmo ano. No ano de 2014, durante uma viagem de férias ao Haiti, resolveu ficar no país, pois não estava gostando do curso. Contudo, permanecia o desejo de estudar e, principalmente, migrar novamente. Durante aquele ano, em contato com um amigo aqui no Brasil pelas redes sociais, Brunel foi informado sobre a abertura do edital do Programa Pró-Haiti na Universidade Federal da Integração Latino-Americana (UNILA). Ainda em 2014, Brunel ingressou em Engenharia das Energias Renováveis na UNILA, onde permaneceu até 2016, quando ingressou na 
UFSM no curso de direito. Brunel relata que suas mudanças de curso se deram por se sentir deslocado e frustrado com os cursos.

A trajetória de Brunel servirá de base para as discussões teóricas a respeito do deslocamento humano em busca de melhores oportunidades. Para além disso, sua trajetória é útil para compreenderemos a dimensão histórico-cultural da diáspora haitiana. A partir da história do Haiti, é possível entender como a mobilidade haitiana é uma parte central da identidade dos meus interlocutores. Busquei compreender a migração como um "fato social total" (SAYAD, 1998), pois entendo que o migrante está em contato com um universo qualificado de sentidos sociais, políticos, econômicos e culturais.

Assim, a mobilidade no contexto social haitiano representa uma ascensão econômica e social do indivíduo que migra. O ser diáspora é um sonho para muitos haitianos para alcançar essa ascensão social. No caso dos interlocutores dessa pesquisa, a decisão de migrar surgiu a partir da experiência de parentes e amigos na migração que transmitiam esse ideal de ascensão social.

O haitiano gosta muito de viajar. [...] Se eu tenho alguém na minha família que migrou? Sim, meu pai antes de eu nascer ficou 5 anos na Martinica, depois quando eu tinha 13 anos ele foi pra Guadalupe também ficou por 5 anos. Ele me disse para viajar. Também tenho um tio que está há 27 anos nos Estados Unidos conseguiu construir uma casa no Haiti e depois em 2001 levou a família para lá. Tenho primas na França que também já tem familia por lá, tem filhos (Joan Luck Joseph, 25 anos, engenharia da computação, março de 2018, grifo meu).

O relato desse interlocutor é interessante porque o desejo de ir ao exterior é alimentado por relatos de parentes próximos que são exaltados como símbolos de sucesso. Segundo Handerson (2015), a construção da casa no Haiti representa um objetivo de muitos haitianos no exterior como uma forma de manter conexão com aqueles que ficam e tornar-se um elemento de distinção. Dessa forma, a diáspora cria valor simbólico a muitos objetos e aqui entra a ideia de "diploma diáspora". O diploma no exterior corresponde para os haitianos um símbolo de sucesso na migração.

Nas entrevistas realizadas ao longo desta pesquisa, apareceram com frequência expressões que remetiam a uma maior valorização daqueles compatriotas que conseguiam sua formação acadêmica no estrangeiro. "O haitiano 
formado no exterior é melhor recebido no país" (TIMAS, 25 anos, enfermagem) ou "o haitiano tem a ideia de mandar o filho fazer a pós-graduação fora porque o diploma de fora vale mais" (Jean Max-Júnior Bendy, 26 anos, Relações Internacionais). Essa busca pelo "diploma melhor" foi relatada em diversas conversas com os interlocutores desta pesquisa, por isso, a partir das discussões teóricas e dos dados etnográficos, discute-se que o diploma também é um objeto diáspora no contexto social haitiano. O diploma, além de um documento formal, torna-se uma categoria moral com valor social diferenciado diante dos familiares que estão no Haiti.

[...] certos diplomas - por exemplo, aqueles que na França, são atribuídos pela Grandes Écoles - garantem, sem outras garantias, uma competência que se estende muito além do que, supostamente, é garantido por eles, com base em uma cláusula que, por ser tácita, impõe-se, antes de tudo, aos próprios portadores desses diplomas que, deste modo, são intimados a assenhorear-se realmente dos atributos que, estatutariamente, Ihes são conferidos. (BOURDIEU, 2011, p. 29).

A educação é um capital cultural de diferenciação e distinção em muitas sociedades. O diploma assume, conforme exposto por Pierre Bourdieu, o símbolo de distinção entre os seus portadores e os não portadores e assume a diferenciação com base nas imposições sociais sob os seus portadores. No caso haitiano em que a educação é um bem de luxo, pois o sistema educacional haitiano é definido conforme as classes sociais, concretizando o objetivo de formar elites separadas das classes populares (JOINT, 2008), a obtenção do diploma é uma distinção social acentuada. Essa desigualdade do sistema de ensino haitiano se confirma com os dados oferecidos pelo Ministério da Educação Nacional e da Formação Profissional (2007), que apontam que no nível pré-escolar, apenas 5,5\% das escolas são públicas. No ensino fundamental, nos ciclos 1 e 2, são $8 \%$ as escolas públicas e o terceiro ciclo e o ensino médio representam apenas $9 \%$. Esses dados demonstram um setor público que se estagnou nos últimos anos, enquanto o setor privado continua sua expansão e é responsável por cerca de $85 \%$ da educação básica haitiana. 
Com a reforma Bernard de $1982^{5}$ e o Plano Nacional de Educação e Formação de 1997, o ensino fundamental foi reorganizado e divido em três ciclos (conforme se observa na figura abaixo), sendo os dois primeiros ciclos obrigatórios e gratuitos no plano legal, que diz respeito às crianças de 6 a 11 anos cursam (o que equivale, no Brasil, do primeiro ao sexto ano). Para que a criança avance em cada um desses ciclos do ensino fundamental, há uma avaliação nacional. O Ensino Médio é um ciclo com quatro anos de duração, baseado em três áreas de conhecimento: uma geral, uma pedagógica e outra profissional. Nesse estágio da formação, segundo os meus interlocutores, as provas finais são divididas em seções conforme o interesse dos alunos desde o início do Ensino Médio (HAITI, 2011).

A título de exemplo, divide-se em seções a) filosofia, cultura geral e sociologia; b) letras, línguas, outras de humanas; c) matemática e física; d) biologia, química, geologia. Cada uma dessas seções representa uma área do conhecimento que os estudantes vão se "especializando" durante o Ensino Médio para ingressar na faculdade, uma vez que eles têm mais horas-aulas daquelas disciplinas referentes à seção escolhida. Segundo eles me relataram, você escolhe uma das seções e um mês antes do exame o Ministério da Educação Nacional e da Formação Profissional faz o sorteio de qual disciplina será a prova de cada seção. $O$ ensino de escolas haitianas, principalmente os poucos recursos humanos, são tecnicistas, o que mais tarde acarreta na dificuldade de ingresso nas universidades.

O resultado dessas desigualdades é uma oferta escolar inadequada para a demanda, representando, segundo o censo escolar, em mais de 500 mil crianças em idade escolar sem acesso à educação, contribuindo para o aumento dos mais de 3 milhões de analfabetos do país (HAITI, 2011). Esses dados se refletem no ensino superior, cuja única universidade pública é a Universidade do Estado do Haiti (UEH), a qual apresenta poucos cursos centralizados na cidade de Porto Príncipe. Com o terremoto de 2010, a maioria das instituições de ensino superior do país foi afetada na estrutura física e nos recursos humanos (NASCIMENTO; THOMAZ, 2010).

O terremoto afetou profundamente os interlocutores desta pesquisa na decisão de migrar e buscar a continuação de seus estudos fora do país. Dos 7

\footnotetext{
${ }^{5}$ A reforma Bernard de 1982 foi uma das maiores reformas do sistema educacional haitiano. É a partir desta reforma que o Créole foi admitido como língua oficial para a formação das crianças. Contudo, incluiu uma tecnicidade ao ensino da rede pública, aumentando ainda mais as diferenças entre as camadas empobrecidas e a elite haitiana.
} 
participantes, apenas um, Jean Max-Bendy Junior, já estava cursando a graduação na vizinha República Dominicana. A opção por cursar uma faculdade fora do Haiti resultava do desejo de obter distinção entre os demais familiares, segundo o relato do próprio Jean Max-Bendy Junior. Os demais estavam em Porto Príncipe e vivenciaram a destruição física das universidades públicas e privadas em decorrência desse episódio.

A decisão de buscar a continuidade dos estudos fora do Haiti e a escolha do Brasil para os interlocutores desta pesquisa foi em função da realidade econômica que o Brasil vivia à época de 2012 e 2013. O crescimento econômico e as oportunidades de emprego em função dos Grandes Eventos - Copa de 2014 e Olímpiadas de 2016 - tornaram o Brasil a janela de oportunidade que esses haitianos queriam. Segundo o relato deles, a viagem que a presidente Dilma Rousseff realizou no ano de 2012 para o Haiti atraiu muitos deles devido ao discurso sobre a oportunidade de estudar no Brasil. Todos os interlocutores desta pesquisa chegaram ao Brasil a partir de 2013 com o sonho de conquistar o diploma. Contudo, alguns encontraram um país com poucas oportunidades para os migrantes, como é o caso de Josaphat, Joan Luck Joseph, Loveruture e Faustin, que foram obrigados a se inserir no mercado de trabalho para garantir seu sustento. Apesar da frustração inicial, o sonho de conseguir um diploma de ensino superior no Brasil não cessou e quando a oportunidade surgiu, eles abandonaram seus empregos em busca do sonho, conforme é exemplificado pelo relato de Loverture.

Desisti do emprego para realizar meu sonho: ser um internacionalista. Eu comecei a estudar Relações Internacionais na UNIRITTER, no primeiro semestre consegui bolsa de $70 \%$, no segundo não consegui. O hotel prometeu pagar $50 \%$ da bolsa, mas eu só conseguiria fazer menos disciplinas, então eu não consegui a bolsa porque para eles pagarem $50 \%$ eu teria que fazer 5 disciplinas e levar o comprovante de matrícula antes das aulas. A ideia de eu me inscrever aqui veio de um amigo que viu o edital e me passou o e-mail do MIGRAIDH. Tudo isso é um sonho. Eu tive esse sonho faz tempo, eu tinha vontade de conhecer o mundo, porque meu pai me deu essa oportunidade. Fui três vezes para a República Dominicana, aprendi o espanhol como língua "enamorada", o Francês como língua bonita e o inglês como comercial. No meu país, quando você termina o ensino médio, só tem uma opção: estudar, porque não tem emprego (Loverture, 28 anos, Relações Internacionais). 
Os jovens que trabalhavam abdicaram de suas responsabilidades financeiras com as famílias no Haiti, de modo a garantir maiores ganhos com o diploma em mãos. O caso de Loverture ilustra isso, pois ele é casado e durante esse período de estudos, a esposa tem garantido o sustento. Segundo ele, é um sacrifício necessário para um bem maior: tornar-se um internacionalista no Brasil. O diploma é, portanto, a categoria norteadora da migração dos interlocutores da presente pesquisa. É com base nele que muitos rearranjos são feitos sobre papéis de gênero, envio de remessas e outras releituras a partir do desafio de alcançar o "diploma diáspora".

\section{INSERÇÃO DOS ESTUDANTES HAITIANOS NO AMBIENTE ACADÊMICO DA UFSM}

As atividades organizadas pelo MIGRAIDH (Grupo de Pesquisa Ensino e Extensão Direitos Humanos e Mobilidade Humana Internacional) e pelo Comitê Representativo dos Imigrantes e Refugiados na UFSM são essenciais para compreender como está ocorrendo a inserção dos estudantes haitianos no ambiente acadêmico. No ano de 2018 , os próprios ingressantes organizaram um Comitê Representativo com o objetivo de criar um intermédio no diálogo com as instâncias burocráticas da universidade. Os ingressantes realizaram as eleições no início do ano de 2018 de seus representantes a partir de critérios definidos por eles próprios, como: estar há mais tempo na universidade, o candidato deveria concorrer para apenas um cargo, seriam desclassificados candidatos que chegassem atrasados no dia da eleição e foram distribuídos seis cargos. Dos interlocutores da presente pesquisa, Timas, Brunel, Josaphat e Faustin participam da gestão 2018-2019.

No ano de 2018, o Comitê realizou diversos debates a respeito da acessibilidade linguística dentro da universidade, com reuniões com a Pró-Reitoria de Graduação e os professores do Departamento de Letras. O Português para Estrangeiros é um programa importante para o acesso às normas do idioma. Diferentemente de programas como o PEC-G (Programa Estudante Convênio Graduação) e o PEC-PG (Programa Estudante Convênio Pós-Graduação), os ingressantes não tinham a obrigatoriedade de aprovação no Celpe-Bras, certificado de proficiência em língua portuguesa, antes do início dos cursos, por isso há alguns entraves no acesso ao idioma por parte dos estudantes. 
O idioma foi uma das primeiras pautas dos estudantes, pois a UFSM iniciou a Política de Ingresso antes de uma Política Linguística, gerando desamparo tanto aos estudantes não-falantes de português como para técnicos administrativos e docentes que esbarravam na fronteira linguística ao socializar com aqueles estudantes. No ano de 2018, a instituição lançou sua Política Linguística voltada especialmente a necessidade de internacionalização (UFSM, 2018). Apesar da Resolução 041/2016 ser considerada no documento, na descrição das ações o foco está no ensino de idiomas estrangeiros aos estudantes nacionais e no aprimoramento do ensino da Língua Brasileira de Sinais (LIBRAS), enquanto que o Português para Estrangeiros aparece em segundo plano na política. $O$ Departamento de Letras tem se esforçado em disponibilizar cursos de Português para Estrangeiros a fim de responder as demandas dos estudantes ingressantes da Resolução 041/2016.

O Comitê também realizou ao longo do ano de 2018 reuniões para discussão da estrutura do próprio órgão, das quais participaram em sua maioria os ingressantes do sexo masculino. Percebeu-se, ao longo da presente pesquisa, a baixa participação das mulheres nas reuniões do Comitê. Elas são minoria absoluta em comparação ao número de ingressantes masculinos: são 11 mulheres em um total de 53 migrantes.

Os estudantes ingressantes participaram de projetos de ensino, pesquisa e extensão a partir de nove bolsas oferecidas pela Pró-Reitoria de Extensão com o intuito de garantir a permanência dos ingressantes. Além disso, a Universidade ofereceu a todos os ingressantes pela Resolução o Benefício Socioeconômico, que garante a moradia na Casa do Estudante e a gratuidade no Restaurante Universitário. Esses incentivos permitiram aos jovens participantes desta pesquisa o acesso a uma educação de qualidade e aproximou o sonho do "diploma diáspora" de suas realidades. Muitos encontraram dificuldades financeiras em se manter, pois as bolsas específicas para os ingressantes atenderam a poucos estudantes.

A saída encontrada por alguns foi oferecer aulas de francês a colegas conhecidos auxílio nos testes de proficiência em língua francesa. Outro entrave para esses estudantes é o peso dos estudos para sua vida, pois a permanência do Benefício Socioeconômico, assim como para brasileiros, é condicionada a manutenção de um padrão de aprovação nas disciplinas. Como a maioria dos 
estudantes está matriculada em cursos de exatas, com alto índice de reprovação na Universidade, Ihes foi oferecido monitoria para acompanhar o desempenho acadêmico dos estudantes.

Houve também a inserção dos estudantes em grupos de pesquisa dentro dos seus cursos, como é o caso do projeto Saúde pelo Haiti (Santé pour Haiti) e Energia para todos (Energie pour tous), realizado pelo Instituto Nacional de Ciência e Tecnologia em Geração Distribuída de Energia Elétrica (INTC). No ano de 2018, também foi realizado um curso de Iniciação Científica, onde foi discutido como eles poderiam desenvolver suas pesquisas dentro da Universidade. Esse curso foi uma parceria do MIGRAIDH e do Comitê, sendo realizado aos sábados, onde grande parte da pesquisa de campo da presente investigação foi realizada. Os estudantes questionavam como eles poderiam organizar seus currículos no decorrer da graduação para concorrer nos processos seletivos de mestrado posteriormente. Como muitos relataram em seus países de origem, fazer pesquisa era algo difícil e custoso, por isso muitos queriam abraçar todas as possibilidades que o Brasil tinha a oferecer.

Os estudantes ingressantes também participaram do NEAB (Núcleo de Estudos Afro-brasileiros) da universidade, contribuindo com os debates a acerca da produção científica de outros países sobre as relações raciais. Os haitianos, principalmente, contribuíram com o debate acerca do porquê o Brasil ignora a produção de pensadores como Joseph-Anténor Firmin, um antropólogo haitiano cuja obra Essai sur l'égalité des races humaines (1885) não é traduzida no português e é pouco estudada no Brasil. Eles também se inseriram nas comissões dentro da Coordenadoria de Assuntos Estudantis da Universidade, que é um órgão executivo vinculado ao Gabinete do Reitor. As comissões nas quais os ingressantes fazem parte são a Comissão Étnico-Racial e a Comissão Social. A primeira discute as relações raciais dentro da universidade, mobiliza ações de combate ao racismo e a segunda acompanha os universitários cotistas de baixa renda. Os estudantes representantes em ambas as comissões fazem parte do Comitê Representativo dos Imigrantes e Refugiados da UFSM.

No ano de 2019, o Comitê Representativo, em parceria com o MIGRAIDH e a Pró-Reitoria de Extensão da UFSM realizaram o evento "Diálogos e (Inter) culturalidade: Diálogos Sociopolíticos desde o Sul Global”, no qual os estudantes 
debateram a política de seus países de origem, bem como apresentaram culturalmente seus países para além dos estereótipos existentes sobre estes, que são, em sua maioria, periféricos. Além disso, os estudantes conseguiram produzir um documentário em parceria com a TV Campus intitulado "Migrar não é delito", no qual eles apresentam os projetos aos quais estão vinculados e como está a inserção deles na instituição. Aos poucos, os estudantes ingressantes estão se inserindo nas estruturas da Universidade, contudo, no que tange às relações de afeto e amizade, ainda há um longo caminho a percorrer: "eu não tenho amigos aqui ainda. Tipo, eu tenho colegas. Porque colega e amigos são duas coisas diferentes. Amizade é uma coisa mais profunda. Mas os colegas do curso, eu os acho bem queridos, bem recebidos" (fala de um participante do documentário "Migrar não é delito").

\section{CONSIDERAÇÕES FINAIS}

O presente artigo objetivou demonstrar a partir da experiência da Universidade Federal de Santa Maria como está a inserção dos estudantes migrantes que participam de políticas de acesso ao ensino superior através do convênio entre as Instituições de Ensino Superior e a Cátedra Sérgio Vieira de Mello.

A política de ingresso de migrantes e refugiados é uma ação afirmativa importante para fundar uma universidade pluriepistêmica (CARVALHO; FLÓREZ; MARTíNEZ, 2017), o que ainda é um dos grandes desafios da UFSM. Esses estudantes também representam corpos pretos que sofrem com questões estruturais: "as estruturas fundacionais do conhecimento das universidades ocidentalizadas são epistemicamente racistas e sexistas ao mesmo tempo" (GROSFOGUEL, 2016, p.28). Dessa forma, uma das reflexões que as instituições devem ter é que, além do ingresso de migrantes e refugiados, é preciso que estejam abertas aos novos saberes e à corporeidade desses estudantes.

A presente pesquisa destacou também que, apesar das condições socioeconômicas do Haiti que implicam em migrações, os estudantes também apontam o sonho de cursar uma universidade como um motivo relevante para migrar. O Brasil tornou-se uma possibilidade para a migração haitiana a partir dos grandes eventos esportivos (a Copa e a Olímpiada) que atraíram mão-de-obra, 
assim como o crescimento econômico vivido pelo Brasil no início da segunda década do século XXI. Com o Programa Pró-Haiti, iniciado em 2010, o sonho de cursar o Ensino Superior no Brasil se tornou ainda mais próximo daqueles que viram seus sonhos destruídos pelo terremoto daquele ano.

Os estudantes têm demonstrado até o momento que podem contribuir para a construção do conhecimento no Brasil inserindo-se em debates científicos como a Jornada Acadêmica Integrada, que acontece todos os anos na universidade. Outro ambiente de inserção desses estudantes é nos órgãos da universidade, como é o caso da participação nas comissões vinculadas à Coordenadoria de Assuntos Estudantis, vinculada ao Gabinete do Reitor, bem como a participação no Núcleo de Estudos Afro-Brasileiros (NEAB) da UFSM. Além disso, destaco também a agência dos estudantes ingressantes ao criarem o Comitê Representativo de Imigrantes e Refugiados da UFSM com o objetivo de discutir suas pautas diante da instituição. Percebe-se que os estudantes têm aproveitado os diversos espaços de diálogo dentro da universidade para garantir sua permanência.

Os interlocutores, aqui apresentados, não representam a população haitiana, que tem sérios índices de subdesenvolvimento e de acesso extremamente restrito à educação. Contudo, com a trajetória desses sujeitos, busquei apresentar a pluralidade que existe na mobilidade haitiana, os sonhos que atravessam fronteiras. O acesso ao ensino superior é um sonho que há muito é alimentado por esses estudantes que têm se inserido nas universidades. Cabe às IES buscarem alternativas para a permanência desses estudantes, uma vez que, sem as políticas socioeconômicas, muitos não têm como continuar a lutar pelo sonho do "diploma diáspora".

Encerro este trabalho com preocupação com o cenário brasileiro de cortes nos investimentos públicos em educação, fazendo com que o sonho do Ensino Superior se torne mais distante para os haitianos - e para os brasileiros também. Desde o segundo semestre de 2018, não houve ingresso de migrantes e refugiados, observados os cortes no orçamento da UFSM e, consequentemente, na assistência estudantil da universidade. Isso leva a temer que a Política de Ingresso 041/2016 caduque por não ter efeito prático: os estudantes que já ingressaram uma hora sairão, e novos migrantes não estão ingressando. Se o cenário não mudar, as 
Instituições de Ensino Superior não terão como abrir novas vagas e as políticas de inclusão ficarão apenas no papel, sem estudantes migrantes e refugiados de fato.

\section{REFERÊNCIAS}

ALPHONSE, Fritznel.; MACEDO, José Rivair. O Programa Pró-Haiti nas universidades públicas brasileiras (2011-2016). Campinas: Temáticas, ano 25, n. 49/50, pp. 233-270, fev/dez, 2017.

BOURDIEU, Pierre. A distinção: crítica social do julgamento. Porto Alegre: Editora Zouk, 2011.

A miséria do mundo. 7.ed. Petrópolis: Editora Vozes, 2008.

BRUNEAU, Michel. Diasporas et espaces transnationaux. Anthropos-Economica, 2004.

BRUNEAU, Michel. Diasporas, transnational spaces and communities. Diaspora and transnationalism: Concepts, theories and methods, v. 3, n. 1, p. 35-50, 2010.

CARVALHO, José Jorge. O confinamento racial no mundo acadêmico brasileiro. São Paulo: Revista USP, n.68, pp. 88-103, 2006.

CARVALHO, José Jorge; FLÓREZ, Juliana; MARTíNEZ, Máncel. El Encuentro de saberes: hacia uma universidad pluriepistémica. IN: AYALA, N.A.C \& RESTREPO, C.A. Saberes Nómadas: derivas del pensamiento proprio. Bogotá: Ediciones Universidad Central, 2017).

CLIFFORD, James. Diasporas. Cultural anthropology, v. 9, n. 3, p. 302-338, 1994.

CNIG- Conselho Nacional de Imigração. Resolução Normativa n.97/2012. Dispõe sobre a concessão do visto permanente previsto no art. 16 da Lei $n^{\circ} 6.815$, de 19 de agosto de 1980, a nacionais do Haiti. Brasília, 2012.

COHEN, Robin. Global diasporas: An introduction. 2. e.d . London: Routledge, 2008.

CSVM. Relatório Anual Cátedra Sérgio Vieira de Mello. 2019. Disponível em $<$ https://www.acnur.org/portugues/wp-content/uploads/2019/09/Relatorio-AnualCSVM Digital.pdf> Acessado em 19 de fevereiro de 2020.

DANTIL, Louis. Desigualdad y participación política de las mujeres en Haití: entre luchas, obstáculos y logros. Buenos Aire: Clacso, 2016.

DUFOIX, Stéphane. Diasporas. London: University of California Press, 2008.

DUTRA, Maria Rita Py. Cotistas negros da UFSM e o mundo de trabalho. Tese de Doutorado em Educação, Universidade Federal de Santa Maria, 2018. 
GEERTZ, Clifford. A Interpretação das culturas. 13 reimpr. Rio de Janeiro: LTC, 2008.

GROSFOGUEL, Rámon. A estrutura do conhecimento nas universidades ocidentalizadas: racismo/sexismo epistêmico e os quatro genocídios/epistemicídios do longo século XVI. Revista Sociedade e Estado - Volume 31 Número 1 Janeiro/Abril 2016, pp. 25- 49.

GUBER, Rosana. La etnografía: método, campo y reflexividad. Bogotá: Grupo Editorial Norma, 2001.

HAITI. Ministère de L'éducation Nationale et de La Formation Professionnelle. La Stratégie Nationale d'action pour l'éducation pour tous. Port-au-Prince, 2007.

HAITI. Ministère de L'éducation Nationale et de La Formation Professionnelle. Plan Opérationnel 2010-2015 Des Recommandations du Groupe de Travail sur l'Éducation et la Formation. Port-au-Prince, 2011.

HALL, Stuart. Identidade Cultural e Diáspora. Revista do Patrimônio Histórico e Artístico Nacional, n.24, p.68-75, 1996.

HANDERSON, Joseph. Diáspora. Sentidos sociais e mobilidades haitianas. Horizontes Antropológicos, n. 43, p. 51-78, 2015.

JOINT, Louis Auguste. Sistema educacional e desigualdades sociais no Haiti: o caso das escolas católicas. Pro-Posições, v. 19, n. 2 (56) - maio/ago, 2008.

NASCIMENTO, Sebastião; THOMAZ, Omar Ribeiro. Da crise às ruínas: Impacto do terremoto sobre o ensino superior no Haiti. Brasília: Ministério da Educação/Capes, 2010.

MALINOWSKI, Bronisław. Argonautas do Pacífico Ocidental. 3 eds. Rio de Janeiro: Abril Cultural, 1984.

MAUSS, Marcel. Sociologia e antropologia. São Paulo: Cosac \& Naify, 2003.

REDIN, Giuliana. Direito de Imigrar: direitos humanos e espaços públicos na sociedade contemporânea. Tese de Doutorado em Direito, Pontifícia Universidade Católica, 2010.

SAFRAN, William. Diasporas in modern societies: Myths of homeland and return. Diaspora: A journal of transnational studies, v. 1, n. 1, p. 83-99, 1991.

SAYAD, Abdelmalek. A Imigração: ou os paradoxos de alteridade. Tradução: Cristina Murachco. São Paulo: Editora da Universidade de São Paulo, 1998. 
SCHILLER, Nina Glick; BASCH, Linda; BLACN-SZANTON, Cristina. Towards a transnational perspective on migration: race, class, ethnicity and nationalism reconsidered. Annals of the New York Academy of Sciences, 1992.

SCHILLER, Nina Glick.; FOURON, G. Laços de sangue: os fundamentos raciais do estado-nação transnacional. Revista Crítica de Ciências Sociais, 1997.

SHEFFER, Gabriel. Diaspora politics: At home abroad. Cambridge: Cambridge University Press, 2003.

STEPICK, Alex. Haitian boat people: a study in the conflicting forces shaping US immigration policy. Law \& Contemp. Probs., v. 45, p. 163, 1982.

TOGETHER. Our aim. 2018. Disponível em <https://together.un.org/our-aim>. Acesso em 8 de maio de 2018.

UEBEL, Roberto. Análise do perfil socioespacial das migrações internacionais para o RS no início do século XXI: redes, atores e cenários da imigração haitiana e senegalesa. Dissertação de Mestrado em Geografia, Universidade Federal do Rio Grande do Sul, 2015.

UFSM. Resolução N.18/2018. Institui a Política Linguística da Universidade Federal de Santa Maria. 2018. Disponível em <https://www.ufsm.br/wpcontent/uploads/2018/08/Resolu\%C3\%A7\%C3\%A3o-018-2018-UFSM.pdf>.

Acessado em 24 de fevereiro de 2020.

UFSM. Resolução N.041/2016. Institui o Programa de Acesso à Educação Técnica e Superior da UFSM para Refugiados e Imigrantes em situação de vulnerabilidade e revoga a Resolução N. 039/10. Disponível em $<$ http://site.ufsm.br/arquivos/uploaded/uploads/8de07789-d9fb-439c-9bf589a378954a4.pdf>. Acessado em 23 de março de 2018.

Recebido em: 17/05/2019

Aprovado em: 19/02/2020 